\title{
Comparison of Old-age Pension Policy in China and Russia: the Common and the Specific*
}

\author{
Chen Tianhong \\ Guangdong Institute of Public Administration, Guangzhou, China; chentianhong2006@163.com
}

\begin{abstract}
Чэнь Тяньхун
Гуандунский Институт государственного управления, Гуанчжоу, Китайская Народная Республика; chentianhong2006@163.com
\end{abstract}

\begin{abstract}
In the process of transforming from planned economy to market economy, both China and Russia faced the issue of pension reform. There are similarities in the reform and development process and the system model of the pension security system in China and Russia. Transition from planned economy to market economy and aggravation of population aging are main reasons for the reform of pension system in both countries. Under the influence of the World Bank and other international organizations, China and Russia have gradually established a multi-tier pension system, with the state, enterprises and individuals sharing the pension costs. Differences also exist in the old-age security system of China and Russia.
\end{abstract}

Keywords: Old-age Pension, China, Russia, Comparison

For citing: Chen Tianhong. Comparison of Old-age Pension Policy in China and Russia: the Common and the Specific // Administrative consulting. 2020. No. 7. P. 68-82.

Для цитирования: Chen Tianhong. Comparison of Old-age Pension Policy in China and Russia: the Common and the Specific // Управленческое консультирование. 2020. №. 7. C. $68-82$.

\section{Introduction}

Both China and Russia transformed from planned economy to market economy in the 1990s. During this process, both countries had reformed the old-age insurance system in order to adapt to the social and economic situation. This paper analyzes the reform process of establishing multi-tier old-age insurance system in these two countries and the current situation of major old-age insurance programs in the second part and third part of this paper. The fourth part of this paper compares the commonness and differences of old-age insurance system in these two countries.

\section{Multi-tier old-age insurance system in China}

China had started the theoretical exploration and practice of the multi-tier old-age insurance system since 1990s. At the beginning of the reform, it was set as a goal to establish a multi-tier old-age insurance system. Before this reform, the responsibility to provide pension benefit was only borne by the basic old-age insurance program, which was funded by national finance. On one hand, this reform can reduce the benefit level of the basic old-age insurance program and the burden of national finance. On the other hand, multi-tier pension system means a new institutional approach has been found to cope with the pressure of aging population in China.

\footnotetext{
${ }^{1}$ This paper is funded by Research on Multi-tier Old-age Insurance System in Guangdong Province, project of Guangdong Institute of Public Administration in 2018 (project number: XYYB201808).
} 
The multi-tier old-age insurance system in China is consisted of basic old-age insurance system, supplementary old-age insurance program and private commercial old-age insurance program. In this part, development process and major characteristics of main old-age insurance programs are analyzed.

\subsection{The first tier - basic old-age insurance system}

The basic old-age insurance system in China is highly fragmented, with different groups of people covered by different programs [1, p. 108]. The basic old-age insurance system is consisted of several old-age insurance programs, such as basic old-age insurance program for government workers, the Urban Employees' Pension Program, National Rural Pension Scheme and Urban Residents' Pension Program. The fragmentation in old-age insurance programs, including fragmentation within programs, results in large differences in the way people are treated concerning social security benefits [1, p. 113]. The fragmentation is also a cause of social inequality. Thus, Chinese central government has implemented reforms to unify basic old-age insurance programs. For instance, government employees and public institutions' workers were covered by separate pension program, paid for out of general revenues. Since 2015, basic old-age insurance program for government workers and other public institutions' workers was gradually reformed. The old-age insurance system for government workers and other public institutions is consisted of two programs, one is the Urban Employees' Pension Program, and the other one is the Occupational Annuity. Besides, the National Rural Pension Scheme and the Urban Residents' Pension Program were merged into one program the Basic Old-age Insurance Program for Urban and Rural Residents.

\subsubsection{Urban Employees' Pension Program}

Urban Employees' Pension Program provides old-age benefits to urban employed workers. The pilot to establish Urban Employees' Pension Program was started in 1995, with a regulation issued by the Central Government in China. Urban Employees' Pension Program contains a social account and an individual account, and is contributed by employers and employees together. This is quite different from the program before this reform, which was paid by state-owned enterprises only.

Contributions. The contribution rate by employers for this program varies across regions in China. The central government recommends a total contribution rate of 28 percent of wages, of which the employee contributes 8 percent to an individual account, which is the same across China. The 20 percent rate the employer contributes to the social account for the basic pension is a standard suggested by the central government. The exact contribution rate for the social account can be decided by local government, and can be higher or lower. A regulation was issued in 2019 to unify contribution rate of social account to be $16 \%$ step by step. Currently, the contribution rate of social account differs in different areas in China. For instance, due to different degrees of population aging, the contribution rates for the social account in Guangzhou city and Shanghai city are 14 percent and 16 percent in year 2020, respectively.

Eligibility. Workers must have contributed 15 years to be eligible for monthly benefits when they retire. The retirement age is 60 for men and women working in certain professions, 55 for female managers, and 50 for other women. Retirement age is reduced for those working in hazardous occupations or who are seriously ill or disabled because of work.

Benefits. The retirement benefit consists of two parts - a basic benefit financed by the employer's contribution and an individual account benefit financed by the employee's contribution. The basic benefit from the social account pension is calculated by multiplying the following two elements. The first element is a percentage determined by total contribution years, where one contribution year equals 1 percent. The second 
element is a number obtained by adding the social average wage of the year prior to the employee's retirement age with the average indexed monthly wage of the employee and then dividing by two. The social average wage used in this calculation is the average wage for the pooling area where the worker resides at the time of retirement. The average indexed monthly wage of the employee is adjusted for wage increases for every year of work before the person retires.

The monthly benefit based on the individual account is the credited balance in the worker's individual account at retirement divided by 139, for both males and females retiring at age 60 . The divisor depends on the age at which the person collects benefits, but not on gender, with it being higher at lower ages. It is 195 for those retiring at age 50 and 170 for those retiring at age 55 in the urban pension system. This calculation does not vary across regions.

Once benefit payments have started for a worker, initial retirement benefits are adjusted to take into account changes in wage and price levels and the financial health of the program.

\subsubsection{Basic Old-age Insurance Program for Urban and Rural Residents}

Starting in 2009, the National Rural Pension Scheme is a voluntary program for people with rural registration aged 16 or older, who are not students and who do not participate in another pension plan. Starting in 2011, the Urban Residents' Pension Program, is a voluntary program for people with urban registration aged 16 or older, who do not have a job. As both programs provide old-age benefits for those who do not have formal jobs in urban areas (depending on whether they have urban or rural registration), the contribution regulation, government subsidy mechanism, eligibility requirements and benefits are quite similar. In the central government policy of establishing the Urban Residents' Pension Program in 2011, local governments are allowed to unify the National Rural Pension Scheme and the Urban Residents' Pension Program, which is a change that reduces fragmentation in old-age benefit provision. In 2014, these two programs were merged into one program - Basic Old-age Insurance Program for Urban and Rural Residents.

Contributions. As participants in the National Rural Pension Scheme and the Urban Residents' Pension Program do not have a formal job, anyone meeting the age requirements can contribute to these programs regardless of earnings, and the amount of the individual's contributions is not a fixed amount related to earnings. In the National Rural Pension Scheme, the contribution level regulated by central government is 100 to 500 yuan per year, divided into 100 yuan increments ${ }^{1}$. Similarly, in the Urban Residents' Pension Program, yearly contribution amount varies from 100 yuan to 1,000 yuan, divided into 100 yuan increments ${ }^{2}$. Participants can choose their contribution level within this range. But as both programs are managed by the county (district) or municipal government, the range of choice of contribution levels differs between different areas.

Local governments subsidize, through a matching contribution, the contributions of participants in the National Rural Pension Scheme and the Urban Residents' Pension Program. The lowest matching contribution, set by the central government, is 30 yuan per participant per year in both programs. Local governments, however, can raise the matching rate according to the financial ability of the government.

Eligibility. In both programs, to receive benefits, the person must have contributed 15 years and be at least 60 years old (the eligibility age for retirement). People aged

\footnotetext{
${ }^{1}$ The Central Government of China. (2009) [Electronic resource]. URL: http://www.gov.cn/zwgk/2009-09/04/content_1409216.htm (accessed: 20.04.2020).

${ }^{2}$ The Central Government of China. (2011) [Electronic resource]. URL: http://www.gov.cn/zwgk/2011-06/13/content_1882801.htm (accessed: 20.04.2020).
} 
60 or older before the start of the system can receive the basic benefit from government without having contributed.

Benefits. Both the National Rural Pension Scheme and the Urban Residents' Pension Program provide benefits to two different groups of people. The first is people who are currently age 60 or older, both for men and women. The basic benefit is 55 yuan a month in both programs and is financed by the central government in the central and western parts of China, but in the more prosperous eastern provinces it is financed half by the central government and half by the local governments [2, pp. 49-70]. Localities can increase the benefit amount above 55 yuan a month if they have the financial resources to do so.

The second group of people in these two programs is participants who are younger than age 60 and must contribute in order to receive benefits when they reach age 60 . This benefit is provided based on the accumulation in the participant's individual account from the participant's contributions, accrued investment returns and non-contributory basic benefit amount.

\subsubsection{Coverage and fund accumulation of basic old-age insurance program}

The basic old-age insurance system develops fast in terms of participants and fund accumulation. For instance, the number of participants in the Urban Employees' Pension Program was 257.07 million in 2010, and it grew to 434.82 million by the end of year 2019. The number of participants of Basic Old-age Insurance Program for Urban and Rural Residents was 102.77 million in 2010, this number increased to 532.66 million in 2019 (as show in graph 1). It should be noticed that the National Rural Pension Scheme and the Urban Residents' Pension Program were established in 2009 and 2011, respectively. So the number of participants of the Basic Old-age Insurance Program for Urban and Rural Residents in $\mathbf{2 0 1 0}$ only referred to participants of the National Rural Pension Scheme. Total number of participants in the basic old-age insurance program was 967.48 million by the end of 2019. It demonstrates that the participation rate of basic old-age insurance program in China is quite high.

With the continuous development of basic old-age insurance system and the increasing number of people participating in it, the income, expenditure and accumulated balance of the basic old-age insurance system have all increased greatly. As show in Table 1, Fund income, fund expenditure and accumulated balance of the Urban Employees' Pension Program in year 2010 were 1342 billion, 1055.5 billion and 1536.5, respectively. These numbers increased to 5206.3 billion, 4878.3 billion and 5418.1 billion, respectively. By the end of 2019, fund income, fund expenditure and accumulated balance of the Basic Old-age Insurance Program for Urban and Rural Residents were 402 billion, 311.4 billion and 815.6 billion, respectively, which were much smaller than that of the Urban Employees' Pension Program. This is because the contribution level of the Urban Employees' Pension Program is correlated with wage and is much higher than the contribution level of the Basic Old-age Insurance Program for Urban and Rural Residents. As it is showed in Graph 1, by the end of 2019, total number of participants in the Urban Employees' Pension Program (434.82 million) was lower than participants in the Basic Old-age Insurance System for Urban and Rural Residents (532.66 million).

\subsection{The second tier - supplementary old-age insurance system}

Enterprise Annuity and Occupational Annuity jointly constitute the second tier of China's oldage insurance system. These two programs are supplements to the Urban Employees' Pension Program and are provided to different groups of people. Enterprise Annuity is a voluntary old-age insurance program for enterprise employees and is contributed by enterprises and employees together. Occupational Annuity is kind of a mandatory program and is provided to government workers and other public institutions' workers. The Enterprise Annuity program was started in 2004 and the Occupational Annuity in 2015. 


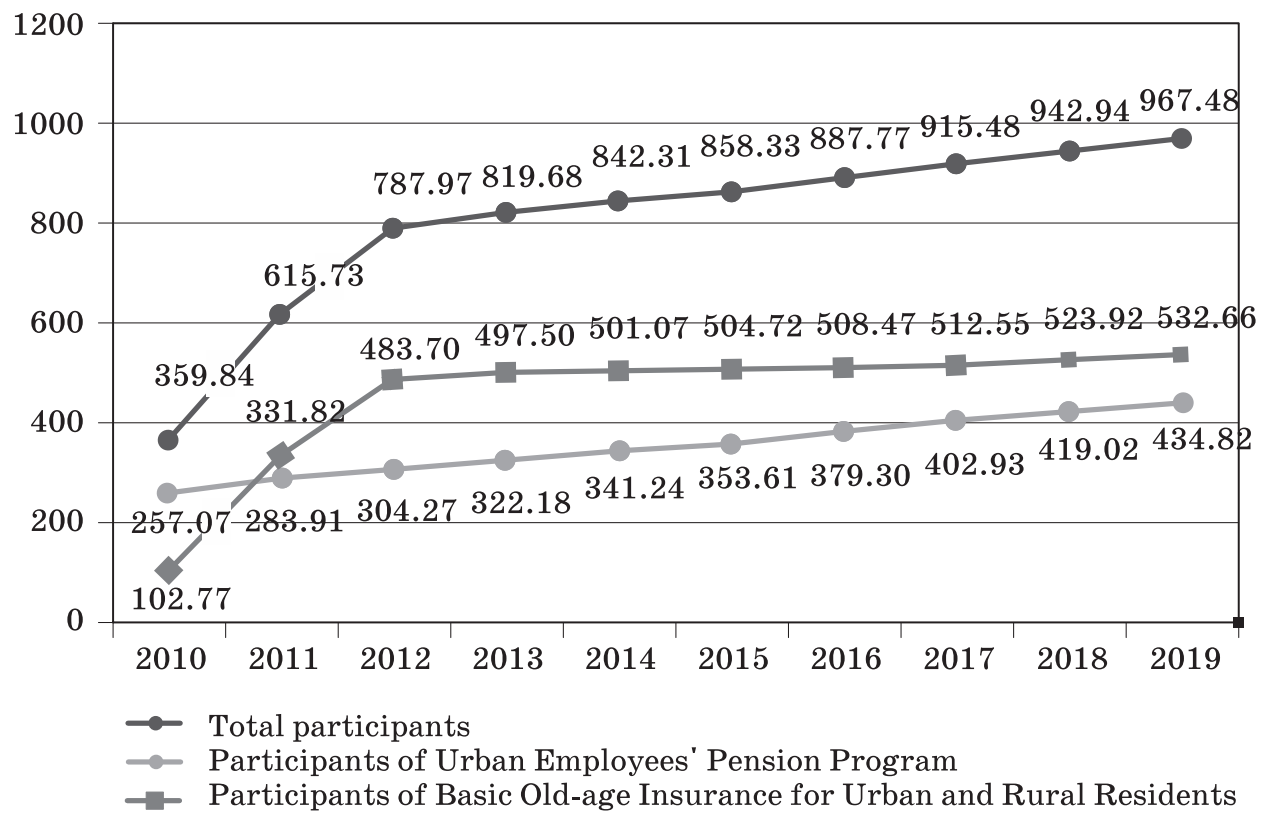

Graph 1. Number of participants in basic old-age insurance programs in China (Unit: Million)

Sources: Ministry of Human Resources and Social Security of the People's Republic of China; Statistical bulletin on the development of human resources and social security undertakings [Electronic resource]. URL: http://www.mohrss.gov.cn/SYrlzyhshbzb/zwgk/szrs/tjgb/(accessed: 20.04.2020).

Contributions. Both Enterprise Annuity and Occupational Annuity are jointly contributed by employers and employees. The total contribution rate of Enterprise Annuity cannot be higher than $12 \%$ of wage, and the contribution rate of the employer cannot be higher than $8 \%$. The contribution rate of Enterprise Annuity can be negotiated and be settled down by employers and employees. The contribution rate of the Occupational Annuity is $12 \%$, with the contribution of employers and employees being $8 \%$ and $4 \%$, respectively. The contributions of Enterprise Annuity and Occupational Annuity are put into individual accounts.

Eligibility. Participants of the Enterprise Annuity and the Occupational Annuity can receive benefits when they arrive at retirement age or when they lose work ability entirely. When participants of these two programs migrate to other countries, they can apply for lump-sum payment of accumulated benefits of the individual account. Balance of these two programs is inheritable.

Benefits. Both Enterprise Annuity and Occupational Annuity are defined contribution programs. Benefits of these two programs are related to accumulation of contributions. Participants of Enterprise Annuity can choose to receive benefit monthly, in installments or in a lump sum. Participants of Enterprise Annuity can also use all or part of the funds in the individual account to purchase commercial old-age insurance products. In this case, participants receive benefits from commercial old-age insurance program according to the insurance contract regulations. Participants of Occupational Annuity can receive benefits monthly, or use all of the funds in the individual account to purchase commercial old-age insurance products and receive benefits according to insurance contract regulation.

Participants. Total number of participants in the Enterprise Annuity increased from 2008 to 2018. In graph 2, total number of participated enterprises was 33,100 in 2008, 
Fund income, expenditure and accumulated balance of basic old-age insurance system, from 2010 to 2019 (Unit: billion)

\begin{tabular}{|l|c|c|c|c|c|c|}
\hline \multirow{2}{*}{ Year } & \multicolumn{2}{|c|}{ Urban Employees' Pension Program } & \multicolumn{3}{c|}{$\begin{array}{c}\text { Basic Old-age Insurance Program } \\
\text { for Urban and Rural Residents }\end{array}$} \\
\cline { 2 - 7 } & $\begin{array}{c}\text { Fund } \\
\text { income }\end{array}$ & $\begin{array}{c}\text { Fund expendi- } \\
\text { ture }\end{array}$ & $\begin{array}{c}\text { Accumulated } \\
\text { balance }\end{array}$ & $\begin{array}{c}\text { Fund } \\
\text { income }\end{array}$ & $\begin{array}{c}\text { Fund } \\
\text { expenditure }\end{array}$ & $\begin{array}{c}\text { Accumulated } \\
\text { balance }\end{array}$ \\
\hline 2010 & 1342.0 & 1055.5 & 1536.5 & $45.3^{\text {a }}$ & $20.0^{\text {a }}$ & $42.3^{\text {a }}$ \\
\hline 2011 & 1689.5 & 1276.5 & 1949.7 & 111.0 & 59.9 & 123.1 \\
\hline 2012 & 2000.1 & 1556.2 & 2394.1 & 182.9 & 115.0 & 230.2 \\
\hline 2013 & 2268.0 & 1847.0 & 2826.9 & 205.2 & 134.8 & 300.6 \\
\hline 2014 & 2531.0 & 2175.5 & 3180.0 & 231.0 & 157.1 & 384.5 \\
\hline 2015 & 2934.1 & 2581.3 & 3534.5 & 285.5 & 217.7 & 459.2 \\
\hline 2016 & 3505.8 & 3185.4 & 3858.0 & 293.3 & 215.0 & 538.5 \\
\hline 2017 & 4331.0 & 3805.2 & 4388.5 & 330.4 & 237.2 & 631.8 \\
\hline 2018 & 5116.8 & 4464.5 & 5090.1 & 383.8 & 290.6 & 725.0 \\
\hline 2019 & 5206.3 & 4878.3 & 5418.1 & 402.0 & 311.4 & 815.6 \\
\hline
\end{tabular}

So urces: Ministry of Human Resources and Social Security of the People's Republic of China; Statistical bulletin on the development of human resources and social security undertakings[Electronic resource]. URL: http://www.mohrss.gov.cn/SYrlzyhshbzb/zwgk/szrs/tjgb/ (accessed: 20.04.2020).

a Note: The National Rural Pension Scheme and the Urban Residents' Pension Program were established in 2009 and 2011, respectively. So the fund income, expenditure and accumulated balance of the Basic Old-age Insurance Program for Urban and Rural Residents in 2010 was corresponding number of the National Rural Pension Scheme.

and it increased to 87,400 in 2018 . We can see from the increase rate curve in Graph 2 that the increase rate of enterprises was higher than $10 \%$ during 2010 to 2014. It arrived at the highest level in 2012, being $21.83 \%$. Then it decreased to the lowest level in 2016 , being $1.06 \%$. Since 2016, it had increased a little bit, and it was still lower than $10 \%$, being $8.71 \%$ by the end of year 2018 .

In Graph 3, total number of participated employees of the Enterprise Annuity was 10.38 million in 2008 , and it was 23.88 million in 2018 . The increase rate curve in Graph 3 shows that the increase rate was higher than 10\% during 2008 to 2014 . Since then it decreased tremendously, and the increase rate in 2017 was as low as $0.26 \%$.

Data in Graph 2 and Graph 3 indicate that China's Enterprise Annuity has entered a low growth range, with the number of newly participated enterprises and the number of insured employees continuing to decline. How to improve the enthusiasm of enterprises to establish the Enterprise Annuity system and the motivation of employees to participate in the insurance system is an urgent problem.

Accumulation of funds. The development of Enterprise Annuity is uneven in different regions of China. The number of participated enterprises and employees in developed provinces along the east coast of China are higher than those in central and western regions and less developed provinces and cities. For example, Zhejiang, Fujian, Shanghai, Guangdong and Shandong and Beijing have more enterprises providing Enterprise Annuity than other provinces in China. In terms of accumulated funds, Shanghai, Beijing, Guangdong and Jiangsu have higher fund accumulation than other provinces. Detailed information on participated enterprises and accumulated funds in each province of China is provided in Table 2. 


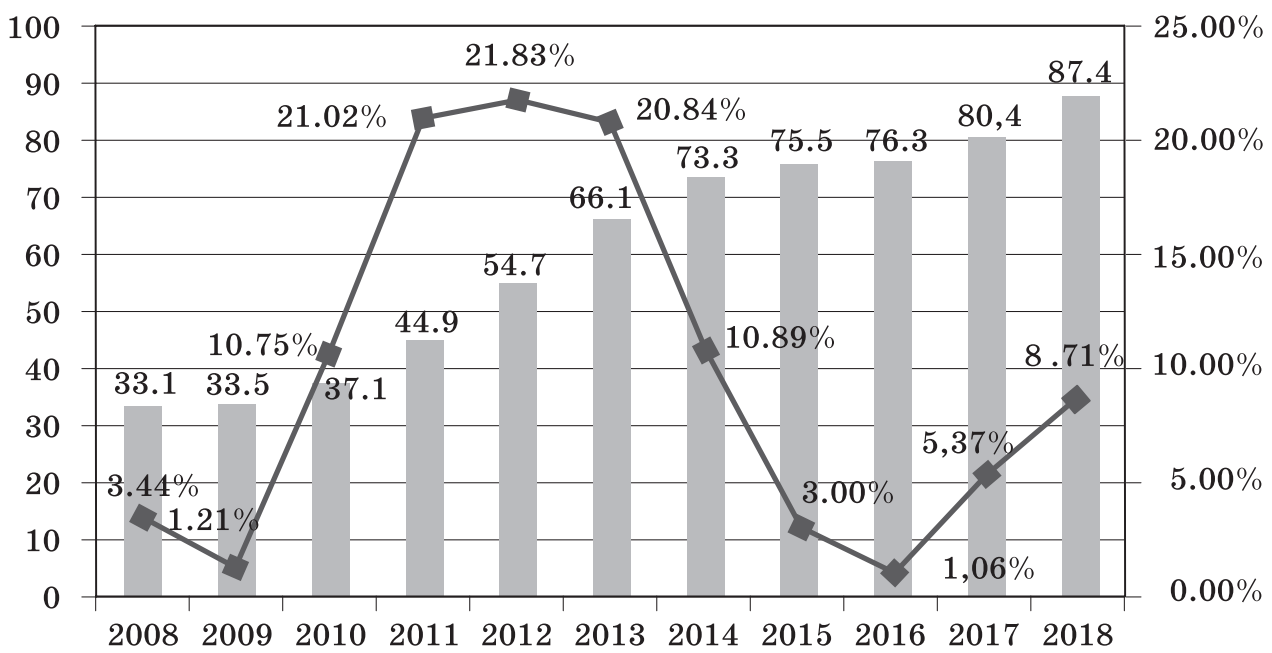

Participated enterprises (thousand) - Increase rate

Graph 2. Participated enterprises of Enterprise Annuity, 2008 to 2018

Sources: Ministry of Human Resources and Social Security of the People's Republic of China; Summary of business data of Enterprise Annuity fund in 2018 [Electronic resource]. URL: http:// www.mohrss.gov.cn/shbxjjjds/SHBXJDSgongzuodongtai/201904/t20190402_313705.html (accessed: 20.04.2020).

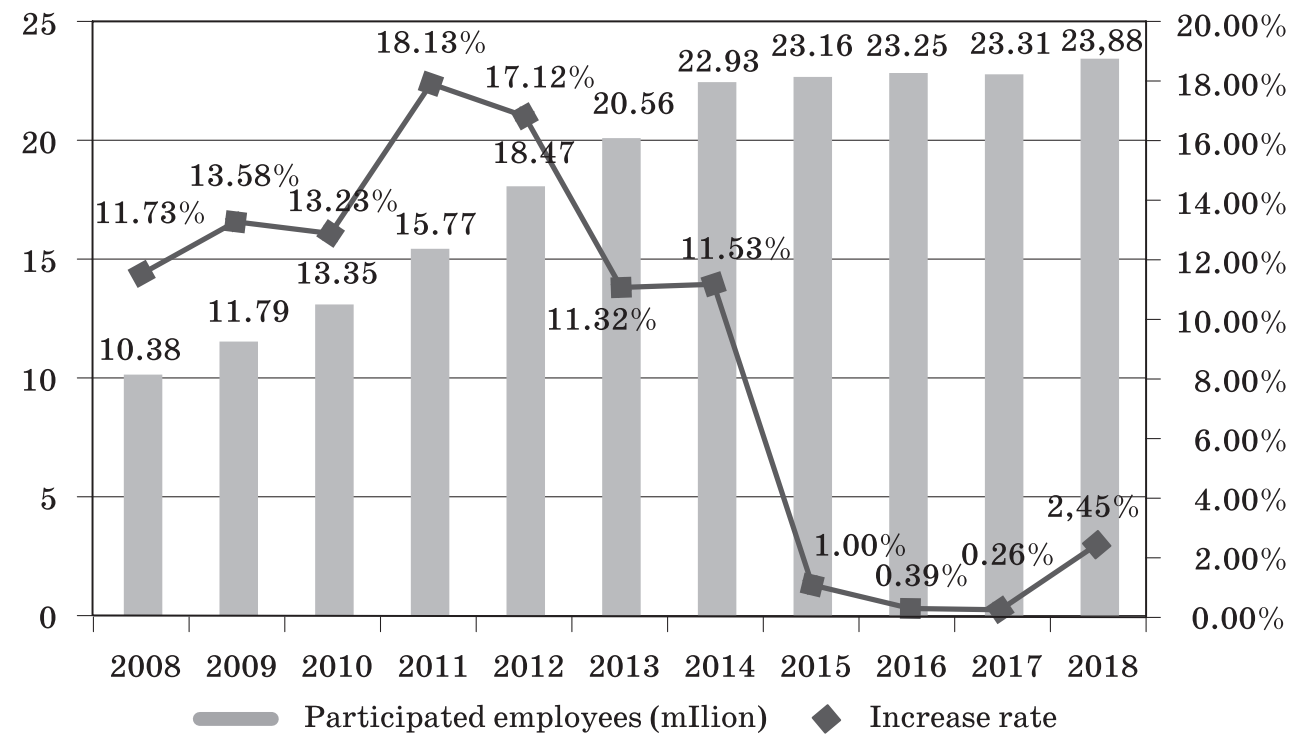

Graph 3. Participated enterprises of Enterprise Annuity, 2008 to 2018

Sources: Ministry of Human Resources and Social Security of the People's Republic of China; Summary of business data of Enterprise Annuity fund in 2018 [Electronic resource]. URL: http:// www.mohrss.gov.cn/shbxjjjds/SHBXJDSgongzuodongtai/201904/t20190402_313705.html (accessed: 20.04.2020). 
Table 2

Participated enterprises and accumulated funds in each province of China in 2018

\begin{tabular}{|l|c|c|l|c|c|}
\hline \multicolumn{1}{|c|}{ Province } & Enterprises & $\begin{array}{c}\text { Accumulated } \\
\text { funds (billion) }\end{array}$ & Province & Enterprises & $\begin{array}{c}\text { Accumulated } \\
\text { funds (billion) }\end{array}$ \\
\hline Zhejiang & 15,077 & 36.7 & Shaanxi & 979 & 23.8 \\
\hline Fujian & 13,473 & 29.6 & Jiangxi & 944 & 11.0 \\
\hline Shanghai & 9,358 & 73.1 & Shanxi & 917 & 30.2 \\
\hline Guangdong & 4,855 & 50.9 & Hebei & 876 & 14.8 \\
\hline Shandong & 3,577 & 34.5 & Xinjiang & 836 & 8.7 \\
\hline Beijing & 3,472 & 54.5 & Chongqing & 700 & 7.5 \\
\hline Guangxi & 2,888 & 8.5 & Hunan & 675 & 13.9 \\
\hline Jiangsu & 2,835 & 39.9 & Neimenggu & 599 & 12.0 \\
\hline Liaoning & 2,355 & 17.9 & Jilin & 520 & 7.9 \\
\hline Tianjin & 1,493 & 10.4 & Gansu & 475 & 10.6 \\
\hline Anhui & 1,455 & 28.3 & Guizhou & 389 & 10.6 \\
\hline Yunnan & 1,343 & 19.3 & Ningxia & 341 & 3.1 \\
\hline Sichuan & 1,224 & 19.2 & Hainan & 216 & 0.8 \\
\hline Henan & 1,212 & 19.6 & Qinghai & 203 & 3.1 \\
\hline Heilongjiang & 1,059 & 8.7 & Xizang & 34 & 0.5 \\
\hline Hubei & 1,010 & 21.7 & & & \\
\hline
\end{tabular}

Sources: Ministry of Human Resources and Social Security of the People's Republic of China; Summary of business data of Enterprise Annuity fund in 2018 [Electronic resource]. URL: http:// www.mohrss.gov.cn/shbxjjjds/SHBXJDSgongzuodongtai/201904/t20190402_313705.html (accessed: 20.04.2020).

Funds investment. Enterprise Annuity funds is invested in the capital market. By the end of 2018, the number of enterprise annuity portfolios was 3,929, and the amount of funds invested was about 1,450.2 billion yuan. The weighted average return on enterprise annuities in 2018 was $3.01 \%$. Data in Graph 4 demonstrates that the weighted average rate of return of enterprise annuity fund fluctuated greatly from 2009 to 2018 . For instance, the highest return rate was $9.88 \%$ in 2016 , and the lowest return rate during these ten years was minus $0.78 \%$ in 2011. Data from Summary of business data of Enterprise Annuity fund in 2018 shows that the return on assets of $42.66 \%$ of enterprise annuity fund was between $2 \%$ and $4 \%$, the return on assets of $21.88 \%$ of enterprise annuity fund was between 0 and $2 \%$, the return on assets of $33.51 \%$ of enterprise annuity fund was higher than $4 \%$.

\subsection{The third tier - Individual Tax-deferred Commercial Pension Insurance Program}

Individual Tax-deferred Commercial Pension Insurance Program is the third tier of the multi-tier old-age insurance system in China. Commercial pension insurance is the main undertaker of individual pension plans. It can provide diversified and differentiated pension services for families and individuals, and meet the differentiated needs of residents in wealth management and risk control. Commercial old-age insurance program has developed for more than ten years in China. In 2007, a regulation to pilot commercial pension insurance in Tianjin city was issued by China Insurance Regulatory Commission. However, this experiment was stopped soon, as the tax preference rate was too high. On April 12, 2018, the Ministry of Finance, the State Taxation Administration, the Min- 


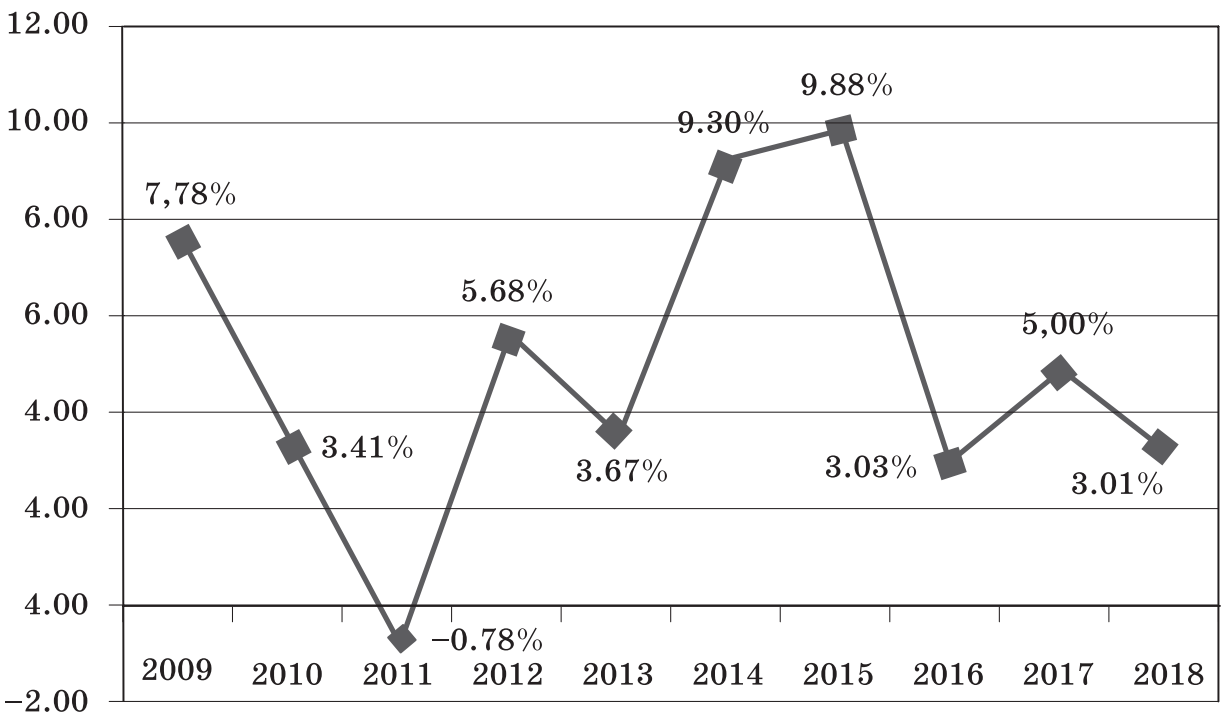

Graph 4. Return rate of Enterprise Annuity funds' investment, 2009 to 2018

So u rces: Ministry of Human Resources and Social Security of the People's Republic of China; Summary of business data of Enterprise Annuity fund in 2018 [Electronic resource]. URL: http:// www.mohrss.gov.cn/shbxjjjds/SHBXJDSgongzuodongtai/201904/t20190402_313705.html (accessed: 20.04.2020).

istry of Human Resources and Social Security of the People's Republic of China and several other departments in China jointly issued the regulation on the pilot project of Individual Tax-deferred Commercial Pension Insurance Program. This pension insurance program was piloted in Shanghai city, Fujian Province and Suzhou city in China.

By March 2019, a total of 23 insurance companies had obtained the qualification of carrying on tax-deferred commercial pension insurance business. By the end of December 2018, the pilot provinces and municipalities had covered a total of about 35,800 cases, with a total premium income of more than 60 million yuan and an average per capita premium of about 1,680 yuan ${ }^{1}$. The insured personnel are mainly ordinary wage earner. It can be concluded that the development of Individual Tax-deferred Commercial Pension Insurance Program during the pilot period was not as good as expected and the scale was not large. This is mainly affected by the following reasons.

First, due to the reform of individual income tax policy in China, the preferential intensity of Individual Tax-deferred Commercial Pension Insurance Program is weakening and the target group of the pilot program is shrinking. According to regulation, during the pilot period, the limit that deducts before tax is $6 \%$ of monthly income or 1000 yuan, according to which is lower. Due to the increase of the individual income tax threshold (from 3500 yuan to 5000 yuan) and the implementation of the individual income tax special additional deduction policy, the pre-tax deduction standard of up to 1000 yuan is too low, which is not very attractive. Besides, even a few participants stop paying for the wait-and-see situation ${ }^{2}$.

\footnotetext{
${ }^{1}$ Guo Gang. Suggestions on the pilot policy of tax-deferred endowment insurance[EB/OL]. 201901-22 [Electronic resource]. URL: https://finance.ifeng.com/c/7jgn8WKWTtM (accessed: 20.04.2020).

${ }^{2}$ Guo Gang. Suggestions on the pilot policy of tax-deferred endowment insurance[EB/OL]. 201901-22 [Electronic resource]. URL: https://finance.ifeng.com/c/7jgn8WKWTtM (accessed: 20.04.2020).
} 
Second, the tax credit process is complex. The method of determining the pre-tax deduction according to the principle of which is lower is inconvenient and too complex to deal with in the process of specific business operations. In addition, according to the current regulations, when individuals purchase the tax-deferred commercial pension insurance by themselves, they need to log on to a designated platform to download the tax-deferred commercial pension insurance deduction certificate and to provide the certificate to the enterprise employer. Then the enterprise employer deducts the number provided in the certificate before counting the individual income tax. This operation process is complex.

\section{Old-age insurance pension system in Russia}

At first, the pension system in Russia worked under the Soviet-era distribution scheme. The pension budget was made of deductions from the total wage bill of enterprises, which was in harmony with planned economy system. China adopted the same old-age security system as that of Soviet-era. The Declaration of Russian State Sovereignty was adopted on June 12, 1990. A new period of history of the country and reorganization of its every state institution began at that time. Notably, social security was one of the first testing ranges for drastic modernization of the socioeconomic structure of new Russia. The shift to a market economy which was accompanied with high unemployment rates and bankruptcies of many large enterprises in the early 1990s made it impossible to support the consolidated pension system.

The Federal Law "On State Pensions in the Russian Federation" was adopted on November 20, 1990. That law set forth the formation of a new type of the pension system in Russia, fully autonomous from the union budget. The new Pension Law of Russia was quite radical for its time, considering the acute political and socioeconomic crisis that took grip of the entire post-Soviet space. The entire system of personal, sectorial, regional and other social benefits and differentiated pension supplements was terminated. A single pension system of Russia was established in its place. Article 1 of the Law "On State Pensions in the Russian Federation" declared "labor and its results" as the main criterion for differentiated terms and norms in the pension system. Hence, only two types of pensions - labor and social - were established to replace the former multifaceted and multilevel pension system.

In order to meet its social commitments, the government had to find better fiscal mechanisms adjusted to the new economic realities. A new financial institution, the Pension Fund of the Russian Federation (PFR), founded on December 22, 1990, was entrusted with those tasks. The country created its first autonomous off-budget system to fund social benefits and to provide sources of pensions. PFR money was formally separated from the federal budget but remained property of the Russian Federation. Such a structure of pension funds management was uncharacteristic of foreign pension models but it played an important role in the development of the social security system in Russia. Inter alia, it provided a certain degree of security to pension funds during periods of financial and economic instability.

Plummeting macroeconomic indicators and a surge in inflation rates in the first half of the 1990s drastically reduced purchasing capacity of the population. Seeking to prevent poverty amongst pensioners, the Russian government decided to regularly increase pensions, prioritizing support to disadvantaged citizens. A fixed-rate compensation for all pensions comparable with the minimal old age pension was introduced in November 1993. Real incomes of pensioners grew as a result. Pensions in Russia were growing more rapidly than wages already in the beginning of 1994, and an average pension was higher than the pensioner's subsistence minimum. Besides, holders of labor and social pensions for the first time ceded their "leadership" amongst poorest Russian citizens to single parents and families with many children. 
Modernization of the social security system and a rise in living standards of the most disadvantaged citizens became a primary objective of social reforms held by the government with the direct participation of the Pension Fund of Russia.

At present, Russia pays the following types of pensions: (1) Insurance pension (including old age; disability; loss of breadwinner) and funded pension; (2) State pension (including long service, old age, disability, loss of breadwinner); (3) Social pension ${ }^{1}$

(1) Insurance pension and funded pension. The Insurance pension program in Russia is compulsory and is the most common form of old-age security for citizens in Russia. A monthly payment compensating for the wage or another type of income citizens were receiving in the period of their work or compensating for the income unemployable members of the family of the insured person lost after his or her death. This program is contributed by employers. The contributions are divided into two parts: insurance part and deposit part. The premium rates for the insurance and savings sections have changed several times. The insurance part is a Pay As You Go program and pays benefits to existing retirees. A fixed-rate payment is established for the insurance part and the payment is subject to annual compensation according to inflation rates of the previous year. The deposit part provides funded pension. This is a confined contribution program and accumulates fund for individual retirement benefit. This is a lifelong monthly payment of pension savings formed with insurance contributions of employers and return on their investment.

An old age insurance pension is the most widely spread type of pension in Russia. Men older than 60 and women older than 55 qualify for this pension on the condition of the required labor record and the minimal amount of pension points (with due account of transitional provisions of the pension laws). Some categories of citizens can qualify for an insurance pension earlier. The lists of works, industries, professions, positions, occupations and institutions (organizations) that qualify for early retirement are approved by the Russian government.

A disability insurance pension is assigned to people with disabilities of the first, second and third groups on the condition of a labor record irrespective of its duration and irrespective of the cause of disability and the time of its appearance. Whether or not the person with disability is employed at the moment of the assignment of pension is not important.

A loss of breadwinner insurance pension is assigned to unemployable members of a dead breadwinner's family for whom the deceased breadwinner was providing. The exception is made for persons whose felony causing the death of the breadwinner is established by court.

(2) State pension. The State pension depends on the state budget allocation and provides benefits to state officials and special social groups. A monthly state payment to citizens compensating for their wage (income) lost upon the end of their federal public service due to old age (disability) retirement, or compensating for the lost income of cosmonauts or test pilots upon the end of their long service and retirement, or compensating for health damage suffered in the course of military service, radiation or man-made accidents, or compensating for disability or loss of breadwinner, or paid upon the achievement of the pension age, or paid to unemployable citizens as subsistence means.

A long-service state pension is assigned to federal civil servants, servicemen, cosmonauts and test pilots.

An old age state pension is assigned to citizens who suffered health damage in radiation or man-made accidents.

\footnotetext{
${ }^{1}$ Pension Fund of the Russian Federation [Electronic resource]. URL: http://www.pfrf.ru/en/ pens_system/ (accessed: 20.04.2020).
} 
A loss of breadwinner state pension is assigned to unemployable family members of killed (deceased) servicemen, citizens who suffered health damage in radiation or man-made accidents, cosmonauts.

A disability state pension is assigned to servicemen, citizens who suffered health damage in radiation or man-made accidents, WWII veterans, holders of the Besieged Leningrad Resident badge, and cosmonauts. The current employment is irrelevant for the assignment of a disability state pension.

(3) Private pension. If citizens choose private pension funds, this part of the funds will be included in the category of private pension. Private (supplementary) old-age security is a flexible form of old-age security, which exists as a supplement to the state pension and compulsory insurance pension. Private (supplementary) pension security includes a variety of private pension funds to which employers or employees themselves can contribute.

After years of reform, Russia now basically has a multi-tier pension system: state pension, mandatory social insurance pension and private supplementary pension. In 2017, the pension and social security system in the Russian Federation involved over 43 million pensioners or $56.58 \%$ of the economically active population of the Russian Federation (over 76 million people). Approximately 16 million people joined the state pension co-funding program. More than 7 million families with children received family (maternity) capital certificates, and over $90 \%$ of them used the lump-sum payment (equivalent to approximately $\$ 10,000$ ) on the improvement of their living conditions.

Table 3

Number of pensioners and pension amount in Russia, 2017(as of December 31)

\begin{tabular}{|l|c|c|}
\hline \multicolumn{1}{|c|}{ Pension type } & $\begin{array}{c}\text { Number of pension- } \\
\text { ers (thousand) }\end{array}$ & $\begin{array}{c}\text { Average value } \\
\text { (ruble) }\end{array}$ \\
\hline Insurance pension: & 39786 & 13306 \\
\hline Old-age & 36311 & 13762 \\
\hline Disability & 2069 & 8530 \\
\hline Survivor & 1406 & 8564 \\
\hline State pension: & 3702 & 9400 \\
\hline Old-age & 415 & 11688 \\
\hline Disability & 45 & 12654 \\
\hline Survivor & 6 & 9987 \\
\hline Long service & 76 & 19956 \\
\hline
\end{tabular}

So urces: 2017 Annual Report of Pension Fund of the Russian Federation [Electronic resource]. URL: http://www.pfrf.ru/en/about/annual_report/ (accessed: 20.04.2020).

\section{Comparison of old-age insurance system in China and Russia}

In the process of transforming from planned economy to market economy, both China and Russia faced with major issues of pension reform. Transition from planned economy to market economy and aggravation of population aging are main reasons for the reform of pension system in both countries. Besides, worldwide professional organizations, such as the World Bank, had influence on both countries in the process of pension reform. In 1994, the World Bank published the report "Averting the Old Age Crisis: Policies to Protect the Old and Promote Growth". This report pointed out that the sustainable development of the old-age insurance system was facing the challenge of population ageing and recommended three-tier old-age insurance as a possible solution 
(namely public pension plans, occupational pension insurance and individual savings plans) [3]. In 2005, the World Bank published the report "Old Age Income Support in the 21st Century: an International Perspective on Pension System and Reform" [4]. The new report extended the three-tier old-age insurance system to a five-tier old-age insurance system. The first tier is the national pension or social pension that provides a fixed type of pension. The pension at this level comes from the state finance, and the citizens do not pay for it, aiming to provide the minimum level of living security for the citizens. The second level is contributive pension system, which is linked to income level to some degree, aiming to replace part of income. The third level is the mandatory individual savings account, which mainly adopts the contribution-determined (DC) fund accumulation mode managed by the pension company. The fourth level is flexible and diverse voluntary insurance. The fifth level is informal support among family members for the elderly, such as transfer payments, medical and housing expenditures within the family.

China and Russia have gradually established a multi-tier pension system, which is quite similar to the structure of the World Bank's suggestion. Multi-tier old-age insurance system can balance the responsibilities of the government, enterprises and individuals. The real essence of multi-tier old-age insurance system is to adjust the structure of the whole pension system and the structure of the pension benefit. It means that multiple old-age insurance programs should be established to share the responsibility and burden of providing old-age benefit.

However, development of multi-tier old-age insurance system in China is uneven and the structure of multi-tier old-age insurance system is out of balance. The system is constituted with three tiers and with several different programs for different groups of people (Graph 5). It can be seen that the primary old-age insurance at the first level is developing rapidly in China, and the participation rate of Urban Employees' Pension Program and Basic Old-age Insurance System for Urban and Rural Residents is relatively high, while the supplementary old-age insurance at the second and third tiers lags behind, resulting in the situation of "the first tier being dominant, and the second and third tiers being weak".

First of all, in terms of participants, the number of people participating in the basic old-age insurance (Urban Employees' Pension Program \& Basic Old-age Insurance System for Urban and Rural Residents) is much higher than the number of people participating in the Enterprise Annuity and private commercial old-age insurance program. The coverage of the second and third tiers of old-age insurance is extremely limited. At the national level, 942.94 million people had participated in the basic old-age insurance

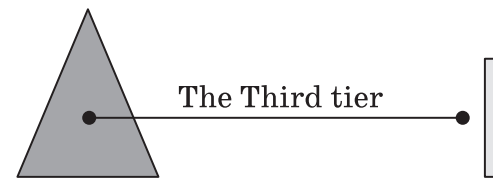

Individual Tax-deferred Commercial Pension Insurance Program (2018)

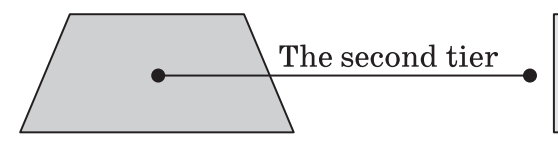

Enterprise Annuity (2004), Occupational Annuity (2015)

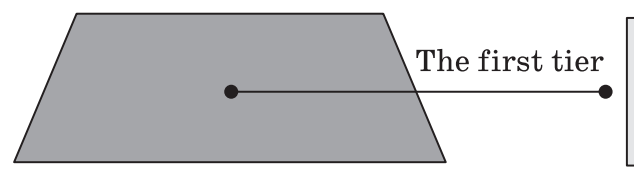

Urban Employees' Pension Program (1997), Basic Old-age Insurance for Urban and Rural Residents (2014)

Graph 5. Multi-tier old-age insurance system in China 
system by the end of 2018, including 523.92 million Urban Employees' Pension Program participants and 420.02 million participants of Basic Old-age Insurance Program for Urban and Rural Residents. By the end of 2018, only 23.38 million people had participated in Enterprise Annuities. According to the data from the National Bureau of Statistics of People's Republic of China, the number of urban employees was 434.19 million in 2018. Thus the participation rate of Enterprise Annuity was estimated to be about 5.5 percent, which is much lower than the participation rate of basic old-age insurance system. The By the end of December 2018, the pilot provinces and municipalities had covered a total of about 35,800 cases of individual tax-deferred commercial pension insurance program. This program is underdeveloped.

Secondly, from the perspective of fund scale, the income and expenditure scale of basic pension fund is much larger than that of Enterprise Annuity fund and individual tax-deferred commercial pension insurance program fund. By the end of 2018, the accumulative balance of the basic pension fund for Urban Employees' Pension Program was 5090.1 billion yuan, the accumulative balance of the basic pension fund for Basic Old-age Insurance System for Urban and Rural Residents was 725 billion yuan, and the accumulative balance of the Enterprise Annuity fund was 1,477 billion yuan. The accumulative balance of the Enterprise Annuity fund accounted for about a quarter of the accumulative balance of the basic old-age insurance fund. Among the life insurance assets of commercial insurance companies in China, excluding related financial products, the accumulated old-age insurance assets are about one trillion yuan, which is far less than the scale of basic old-age insurance fund.

Differences also exist among old-age insurance system in China and Russia.

First, the pension system in Russia is far more comprehensive than the system in China. The pension system in Russia provides comprehensive and synthetic benefits to different groups of people. A series of drastic pension and social security reforms implemented in Russia over the past 30 years significantly broadened functions of the Pension Fund. In addition to paying labor and social pensions, the Pension Fund of Russia collects insurance contributions to the mandatory pension insurance system, pays all types of benefits to benefit holders and poor citizens, issues state certificates of family (maternity) capital to every family giving birth to a second child or more, implements the program of state co-funding of pensions, forms, invests and pays funds of the pension cumulative part to social security system participants and executes many other functions.

By comparison, the old-age insurance pension system in China only provides old-age benefits to participants to meet their basic life needs during retire period. The old-age insurance system in China is more targeted. No spouse benefits and disability benefits are provided in the old-age insurance system in China. Disability benefits are provided by another social insurance program - Work-Related Injury Insurance, in China.

Second, the participation rate of multi-tier old-age insurance system in China is much higher than that in Russia. In China, 942.94 million people had participated in the basic old-age insurance system by the end of 2018, including 523.92 million Urban Employees'

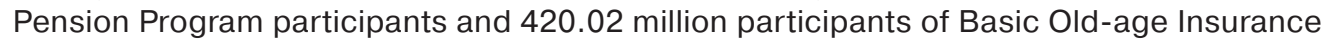
System for Urban and Rural Residents. In 2017, the pension and social security system in the Russian Federation involved over 43 million pensioners or $56.58 \%$ of the economically active population of the Russian Federation (over 76 million people) ${ }^{1}$. The participation rate of old-age insurance program in Russia was lower than that in China. Several reasons can explain for this. In China, central government and local governments provides financial subsidies for participants of Basic Old-age Insurance System for Ur-

\footnotetext{
${ }^{1}$ Data from 2017 Annual Report of Pension Fund of the Russian Federation [Electronic resource]. URL: http://www.pfrf.ru/en/about/annual_report/ (accessed: 20.04.2020).
} 
ban and Rural Residents. This is a strong and effective motivation for improving the participation rate of this program in China.

The Russian government often changes its pension policy for budgetary reasons, and the premium rates for the insurance part and deposit part have changed many times. As the insurance part is used directly to pay pensions to existing retirees, the government adjusted the policy and expanded the insurance part when the budget was tight. In 2005, because of the budget deficit of the Russian Pension fund, the deposit part of all citizens born before 1967 were cancelled, and these funds transferred to the insurance part. In 2013, citizens born in 1967 and after could chose a 2 percent deposit and 10 percent insurance or a combination of 2 percent savings and 14 percent insurance. By 2015, the deposit part became a voluntary part, and citizens can choose to participate or not participate at all. Many changes to the pension policy had also brought confusion to Russian citizens and to some extent had affected the credibility of the government [5, p. 109-120].

\section{Conclusions}

Both China and Russia had gone through similar process of economic reform and oldage insurance system reform. Multi-tier old-age insurance system has been established in these countries. This kind of system can balance the responsibilities of the government, enterprises and individuals. However, old-age insurance system reform has far from being finished. Both countries face the problem of low income and flexible employment groups having little incentive to participate in voluntary pension system. As the social and economic situation of these two countries is changing, both countries need to adjust the old-age insurance system. For instance, both countries are facing decreasing birth rate and increasing percent of old-age population. Population ageing puts pressure on sustainability of old-age insurance program and financial subsidies for oldage insurance system. Besides, economic downturn also puts pressure on old-age insurance system.

\section{References}

1. Tianhong Chen, John Turner. Fragmentation in Social Security Old-Age Benefit Provision in China. Journal of Aging \& Social Policy, 2015 (2). P. 107-122. (in English)

2. Tianhong Chen, John Turner. Extending social security coverage to the rural sector in China. International Social Security Review, 2014 (67). P. 49-70. (in English)

3. The World Bank, Averting the Old Age Crisis: Policies to Protect the Old and Promote Growth, Oxford University Press, 1994. (in English)

4. The World Bank, Old Age Income Support in the $21^{\text {st }}$ Century: an International Perspective on Pension System and Reform, World Bank, 2005. (in English)

5. Chen Yun-ying, He Fang. Russia's Pension System Reform in 2018 under the Current RussianEconomic Background. Northeast Asia Economic Research, 2019 (4). P. 109-120. (in Chinese)

\section{About the author:}

Chen Tianhong, Associate Professor of Guangdong Institute of Public Administration (Guangzhou, People's Republic of China), doctor of management; chentianhong2006@163.com

\section{Об авторе:}

Чэнь Тяньхун, доцент Гуандунского Института государственного управления (Гуанчжоу, Китайская Народная Республика), доктор менеджмента; chentianhong2006@163.com 